\title{
Using Guided Discovery to Improve Students' Retention and Academic Attitudes to Financial Accounting Concepts
}

\author{
Ernest O. Ugwoke $\mathbb{D},{ }^{1}$ Taiwo Grace Olulowo, ${ }^{2}$ and Ige Olugbenga Adedayo $\mathbb{C D}^{3}$ \\ ${ }^{1}$ University of Nigeria, Nsukka, Nigeria \\ ${ }^{2}$ Adekunle Ajasin University, Akungba Akoko, Nigeria \\ ${ }^{3}$ University of the Free State, Bloemfontein, South Africa \\ Correspondence should be addressed to Ige Olugbenga Adedayo; olugbengaige@gmail.com
}

Received 24 October 2020; Revised 18 December 2020; Accepted 21 December 2020; Published 30 December 2020

Academic Editor: Haoran Xie

Copyright (C) 2020 Ernest O. Ugwoke et al. This is an open access article distributed under the Creative Commons Attribution License, which permits unrestricted use, distribution, and reproduction in any medium, provided the original work is properly cited.

\begin{abstract}
Financial Accounting is one of the specialised subjects in the Nigerian senior secondary school curriculum. It is no gain saying that without apposite comprehension of the subject, the goals of its inclusion in the curriculum might not be fully accomplished. Hence, the researchers are in quest of appropriate instructional strategies that entail students' active participation and improve students' learning outcomes (attitude and retention) through practice-oriented research. Consequently, this research determined the effectiveness of guided discovery instructional strategy, in relation to a conventional lecture, on learning outcomes of students in Financial Accounting concepts. This study adopted a nonrandomized pretest, posttest, control group quasiexperimental design with a $2 \times 2 \times 3$ factorial design. 147 secondary school students in level 5 were selected from eight secondary schools in the northern part of a Southwestern state, Nigeria. The research instruments used were Teachers' Instructional Guides on Guided Discovery, Students' Attitude to Financial Accounting Questionnaire $(r=0.89)$ and a 30-item Financial Accounting Retention Test $(r=0.83)$. The analyzed data affirmed that the treatment improved students' attitude $\left(F(1,134)=344.935 ; p<0.05 ; \eta^{2}=0.720\right)$ and retention $\left(F(1,134)=385.431 ; p<0.05 ; \eta^{2}=0.742\right)$ of accounting concepts. This study recommended that teachers should utilize the guided discovery strategy to develop attitudes and knowledge retention of learners in Financial Accounting.
\end{abstract}

\section{Introduction}

Nigeria's national policy on education documented the extensive goals of postbasic education to train learners to live functionally in their higher education and society $[1,2]$. Postbasic education is built on the fundamental literacy, numeric, and practical knowledge obtained at the basic level of education. Postbasic education via its varied programmes gives prospective means of obtaining sophisticated and connoisseur knowledge and proficiency required to advance learning and become useful and responsible members of the society [3]. Financial Accounting is a vocational or technical subject that is offered in postsecondary schools in Nigeria.

Toluwalope [4] stated that the process of collecting, recording, presenting, analyzing, or interpreting financial information for both internal and external users of financial statements is applicable to modern era accounting $[4,5]$. The subject is a requisite to achieving the purpose of incorporating individuals as efficient members needed to accomplish the goal of positively shaping society [6]. Furthermore, Financial Accounting aims to equip learners with values relating to the foundational practices of the discipline, their applications to ultramodern commercial activities and prepare them for further studies in the discipline [7]. Consequently, in Nigeria, it is meant to develop prospective professionals in business-related fields with the capacity to contribute meaningfully to the economic development of the country.

Financial Accounting is an organized and practical subject that cannot be learnt and comprehended through rote learning. Nwaukwa and Okolocha [8] stated that both the teaching and learning of accounting concepts require a 
sound knowledge of the subject matter and concentrated practice of its applications. Though the traditional method of teaching is dominant in Nigerian schools [9], it is not efficient for improving students' learning outcomes in discipline-specific subjects because the method does not give enough room for the active participation of students. The event that often transpires during classroom activities when the conventional method is adopted is that majority of the students are more dormant, unenthusiastic, anxious, or timid to articulate their opinions, thereby interrupting the learning atmosphere and ingenuity of learners during classroom activities. In addition, instructional delivery in this method tends to be one way as it depends solely on the teacher. It also makes available numerous instructional materials and faintly gives learners the opportunity to contribute. This mode of delivering instruction may affect learning outcomes in students with its incessant usage [10].

Furthermore, Phillips [11] opined that delivering of instruction with the conventional method of teaching is informed by the possibility of covering enough grounds and needs of the teacher. This, however, only benefits teacher's satisfaction. The role of students in learning cannot be put aside because whenever they feel unsatisfied with a lesson, the interest and effort exerted in the subject will reduce gradually. Therefore, the dissatisfaction of students could be the source of poor learning outcomes in Financial Accounting as well as the colossal decline of interest in the subject [8].

Learning is a process that brings about relative permanent changes in the behaviour of students after definite practice or experience [12]. Scholars described learning outcomes as the appraisal of students and their achievement of expected results on the completion of certain instructional activities $[13,14]$. These outcomes include changes in students' knowledge retention, skills, attitudes, and other postinstructional changes $[14,15]$. Learning outcomes in students are usually facilitated by adopting an appropriate learning strategy [16, 17]. Okoye [18] submitted that learning strategy has an influence on students' learning outcomes (retention).

Yerizon and Subhan [19], in $\mathrm{Wu}$ and Tai [14], opined that guided discovery involves the delivery of instruction that is consistent with a scientific model that enables students to solve problems in a systematic manner, starting from inspiration, declaration/recognition of the problem, gathering of data, processing of data, authentication and drawing of inference. It is an instructional strategy that equips students with the ability to solve problems. This strategy is student-centered since it gives students the opportunity to investigate, use their discretion, contribute to knowledge, and get information individually or collectively to find a solution to a given task [20]. It stimulates inquisitiveness and promotes students' enthusiasm to discover the answer to problems [21].

Students tend to learn better and deeper when required to search, discover, and build essential information. Guided discovery learning encourages students to learn autonomously, discover a variety of learning contents, and actively construct their knowledge under the guidance of the teacher.
According to Khasanah et al. [22], teachers play significant roles in discovery activities in terms of providing innovation, guidance, and direction. The guidance provided by the teacher is not a rule of thumb that must be followed instead of the needed work procedure direction. It requires students to be fully and actively involved in learning by investigating and discovering their own knowledge that is properly monitored by a teacher.

Nwagbo [23], cited in Afolabi and Akinbobola [24], stated that the guided discovery approach is situated in constructivist learning. Nwagbo [23] posited that the teacher provides illustrative materials for students' self-study, and thereafter, asks questions that elicit critical thinking and knowledge construction in this learning approach. The underlying principle is that when students search, discover, and construct knowledge themselves under the guidance of the teacher, it encourages independent learning, creativity, critical thinking, problem solving, active participation and discourage rote learning, memorizing of materials without understanding, and being passive in the classroom, among others.

There is scholarly evidence that shows that learning via guided discovery strategy promotes students' capability in novelty, inquiry, problem solving, and self-regulating thinking, and constructive inventions in resourceful learning [21, 25]. Bamiro [26] affirmed that guided discovery is a philosophical approach to learning that is embedded in constructivism. Bamiro [26] stated that this approach enables learners to actively participate in the learning process because it affords them optimal freedom and self-determination [26]. It was in the light of this assertion that Hake [27] affirmed that guided discovery could positively influence students' learning outcomes.

Ajewole [28] researched the effectiveness of two scientific instructional methods on students' attitude to concepts in biology. Ajewole [28] reported that students taught with the discovery method had better attitude changes to biology than their counterparts who were exposed to expository and conventional methods. With respect to gender, Imasuen and Omorogbe [29] evaluated gender's influence on students' attitude to Mathematics in junior secondary schools and affirmed a distinction in male and female students' attitudes to Mathematical concepts. This study determined guided discovery's efficacy on learners' outcomes in Financial Accounting concepts, paying attention to gender and socioeconomic status. In the study, learning outcomes were operationally taken as the attitude and knowledge retention of students to Financial Accounting.

In the light of the foregoing, we experimented with the following hypotheses using guided discovery:

$\mathrm{H}_{01}$ : there is no statistically significant improvement in students' attitude to Financial Accounting

$\mathrm{H}_{02}$ : there is no statistically significant improvement in students' retention of Financial Accounting

$\mathrm{H}_{03}$ : gender and socioeconomic status have no statistically significant main effect on students' attitude towards Financial Accounting 
$\mathrm{H}_{04}$ : gender and socioeconomic status have no statistically significant main effect on students' retention of Financial Accounting concepts

$\mathrm{H}_{05}$ : interaction effect of treatment and gender on students' retention of Financial Accounting concepts is not statistically significant

$\mathrm{H}_{06}$ : interaction effect of treatment and socioeconomic status on students' retention of Financial Accounting concepts is not statistically significant

\section{Methodology}

2.1. Research Design. This study adopted the nonrandomized pretest-posttest delayed posttest control group quasiexperimental design [30-35]. The delayed posttest was employed to capture students' retention. The design of this study is schematically presented:

$$
\begin{array}{llllll}
\mathrm{D}_{1} & \mathrm{E}_{1} & \mathrm{D}_{3} & \mathrm{E}_{1} & \mathrm{D}_{5} & \text { Experimental Group } \\
\mathrm{D}_{2} & \mathrm{E}_{2} & \mathrm{D}_{4} & \mathrm{E}_{2} & \mathrm{D}_{6} & \text { Control Group }
\end{array}
$$

Here, $D_{1}$ and $D_{2}$ are pretests of the treatment and control groups. $\mathrm{D}_{3}$ and $\mathrm{D}_{4}$ represent the posttest of treatment and control groups, while $\mathrm{D}_{5}$ and $\mathrm{D}_{6}$ represent the delayed posttest of treatment and control groups

$\mathrm{E}_{1}$-guided discovery teaching strategy

$\mathrm{E}_{2}$-conventional lecture method

Table 1 shows that the $2 \times 2 \times 3$ factorial matrix adopted for this study consisted of an instructional strategy that was manipulated at two levels, namely Guided Discovery Teaching Strategy and Conventional Lecture Method. The mediating variables included socioeconomic status (low, middle, and high) and gender (male and female).

2.2. Selection of Participants. The students in senior secondary schools offering Financial Accounting in Southwest, Nigeria, from which one hundred and thirty-seven (137) students (68 males and 69 females) were selected for this study, had no impending external examinations. Eight intact senior school II classes in eight secondary schools were selected. Guided discovery teaching strategy was used in four of the selected schools (63 students), while the conventional strategy was adopted in the remaining four schools (84 students). The selection of schools for this study was guided by the presence of male and female learners who registered for Financial Accounting, accreditation of the school by the national and regional examination bodies, and geographical location of the school.

2.3. Instruments. Students' Attitude to Financial Accounting Questionnaire (SAFAQ), Financial Accounting Achievement Test (FAAT), Teachers' Instructional Guide on Guided Discovery (IGGD), and Instructional Guide on Lecture Method (TIGCLM) served as the instruments for this study. SAFAQ was designed by the researchers to measure students' attitude towards Financial Accounting. The questionnaire consists of two sections, i.e., $\mathrm{A}$ and $\mathrm{B}$, that elicited students' biographical information and the learners' attitude towards Financial Accounting. SAFAQ consisted of 15 items on a four-point response scale. The items were structured on an ordinal scale ranging from Strongly Agreed (SA), Agreed (A) to Disagreed (D) and Strongly Disagreed (SD).

In scoring the SAFAQ, the scoring of positively structured statements was done in this order: SA-4, A-3, D-2, and SD-1, while the scoring of negatively structured statements was done in the order: SA-1, A-2 D-3, and SD-4. SAFAQ was trial-tested and Cronbach Alpha was used to obtain $r=0.89$. The reliability was tested using Cronbach Alpha because it checks the internal consistency of measurement with polychotomous data. SAFAQ was validated by experts in the Test and Measurement Unit at a reputable state government owned university. The comments, suggestions, and corrections made by the experts were used to improve this instrument.

The FAAT comprised 30 adapted multiple-choice questions from the previous examinations conducted by West African Examinations Council. Every item in FAAT had options A-D with a correct option while others were distracters. The core concepts on which FAAT was based were depreciation of the fixed asset, manufacturing accounts, and accounts for nonprofit making organizations. The reliability of FAAT yielded 0.83 when it was subjected to Kuder-Richardson Formula 21 (KR-21). This was adopted to test the reliability of FAAT because it checks the internal consistency of measurement with dichotomous data. The TIGGDIS and TIGCLM were constructed to guide the instructors in the treatment and control groups to ensure conformity to the experimental and controlled activities. These instructional guides were authenticated by specialists in the field of Business Education (Accounting Option) at a university in Nigeria.

2.4. Procedure. The treatment and collection of data procedures took place in five phases for ten weeks (training of research assistants took place in the $1^{\text {st }}$ week; the $2^{\text {nd }}$ week was devoted to the administration of pretest; and the $3^{\text {rd }}-7^{\text {th }}$ week was used for the application of treatments (Olulowo et al.) [57]. The administration of the posttest was done in the $8^{\text {th }}$ week, while the delayed posttest was administered in the $10^{\text {th }}$ week. In the $10^{\text {th }}$ week, the second posttest was also administered to tin the experimental and control groups to determine the participants' level of retention.

In addition, efforts were made by the researchers to control other superfluous variables such as teacher's effect, test familiarity, and subject interaction variable. For instance, the teachers made sure that diverse lessons were going on concurrently in other SS2 classes to control subject interaction. This reduced itinerant of the students and vetoed disruption. Also, the FAAT was used for the test before treatment, after treatment and delayed posttest. The test items were reshuffled to change the face value to the participants. Data collected during the pretest, posttest, and delayed posttest for the two groups were used to answer the research questions and test the hypotheses for the study. 
TABLE 1: $2 \times 3 \times 2$ factorial matrix.

\begin{tabular}{lcc}
\hline Treatment & Socioeconomic status & Gender \\
\hline & High & Fale \\
Guided discovery instructional strategy E1 & Average & Low \\
& High \\
Conventional lecture method E2 & Average & Low \\
\end{tabular}

The experimental group students were exposed to guided discovery strategy by introducing the selected accounting topics at the set learning pace to participants. This was done with other interrelated steps. The teacher evaluated the participants after these steps and gave take-home assignment. Lessons in the control group students were presented with conventional lecture method using the steps outlined in Adesoji and Ibraheem [36]: The lesson was presented by teacher in the form of a lecture; the teacher explained the topic to participants; participants wrote summaries in the form of chalkboard summary; the teacher answered questions on aspects of the topic that were unclear to participants. The teacher summarized the lesson, asked evaluation questions, and gave take-home assignment to participants.

2.5. Analyzing Data. The data was subjected to descriptive and inferential statistics on the Statistical Package for Social Sciences (SPSS). Mean and standard deviation were utilized to evaluate the performance in the experimental groups across gender and socioeconomic status. The hypotheses were subjected to Analysis of Covariance (ANCOVA). ANCOVA was preferred because of its power to take care of the initial lack of equivalence in the groups since intact classes were used for the study [ [37] in [38]]. The significant differences where they existed were subjected to Bonferroni post hoc analysis.

\section{Findings}

The data generated were presented below based on the hypotheses.

$\mathbf{H}_{\mathbf{0 1}}$ : there is no statistically significant improvement in students' attitude towards Financial Accounting using guided discovery.

Table 2 showS that there was a significant main effect of the treatment on students' attitude towards Financial Accounting $\left(F_{(1,134)}=344.935 ; p<0.05 ; \eta^{2}=0.720\right)$. The effect size of $72 \%$ confirmed that $72 \%$ of the variance in the experimental variable was attributed to the covariates. The product of ANCOVA showed a significant difference in the postattitude scores of participants in Financial Accounting based on the treatment (guided discovery and conventional instructional strategies) given. Thus, hypothesis 1 on students' attitude towards Financial Accounting was rejected. The Estimated Marginal Means was used to determine the magnitude of the significant main effect across treatment groups, presented in Table 3.
Table 3 shows that the attitude of students taught with guided discovery instructional strategy significantly improved $(\bar{x}=45.01)$ than learners in the control group $(\bar{x}=35.84)$. This was mathematically represented as GDIS > CLM. Furthermore, the Bonferroni post hoc test was used to identify the source of the significant difference shown in Table 4.

From Table 4, Bonferroni reported a significant distinction between GDIS and CLM. This, therefore, means that GDIS was statistically more effective than CLM in improving students' attitude.

$\mathbf{H}_{\mathbf{0 2}}$ : there is no statistically significant improvement in students' retention of Financial Accounting using.

Table 5 reports a significant main effect of the treatment on participants' retention in Financial Accounting concepts $\left(F_{(1,134)}=385.431 ; p<0.05 ; \eta^{2}=0.742\right)$. The effect size was $74 \%$ which implied that $74 \%$ dependent variable's variance was attributed to the covariates. The output of ANCOVA presented a significant difference in retention mean scores of participants in Financial Accounting in the treatment (guided discovery and conventional instructional strategies) given. The second hypothesis was, therefore. rejected. The magnitude of the significant main effect across treatment groups was determined across the treatment groups and presented in Table 6.

From the output in Table 5, the students who were exposed to guided discovery instructional strategy retained the treatment better $(\bar{x}=45.01)$ than those in the control group $(\bar{x}=35.84)$. This order was represented as GDIS > CLM. Further, the source of the significant difference obtained in Table 7 was traced using the Bonferroni post hoc test.

The Bonferroni post hoc analysis affirmed the significant disparity between GDIS and CLM in Table 7. This, therefore, means that GDIS was significantly more effective in enhancing students' retention than CLM.

$\mathbf{H}_{\mathbf{0 3}}$ : gender and socioeconomic status have no statistically significant main effect on students' attitude towards Financial Accounting.

Regarding hypothesis three, Table 2 shows that gender had no significant main effect on students' attitude towards Financial Accounting $\left.F_{(1,134)}=1.555, p>0.05 ; \eta^{2}=0.011\right)$. Therefore, the null hypothesis was not rejected. This implied that the differentiation in the postattitude scores of the male and female students was not significant.

Table 2 also shows that the main effect of SES on students' attitude to Financial Accounting $F_{(2,134)}=0.127$, $\left.p>0.05 ; \eta^{2}=0.002\right)$ was no significant. Therefore, the null 
TABLe 2: ANCOVA of postattitude rating of students by treatments, gender, and SES.

\begin{tabular}{lcccccc}
\hline Source & Type III sum of squares & Df & Mean square & F & Sig. & Partial eta squared \\
\hline Corrected model & $3251.202^{\mathrm{a}}$ & 12 & 270.933 & 38.319 & 0.000 & 0.774 \\
Intercept & 428.152 & 1 & 428.152 & 60.554 & 0.000 & 0.311 \\
Pretest & 1854.795 & 1 & 1854.795 & 262.328 & 0.000 & 0.662 \\
Treatment & 2438.872 & 1 & 2438.872 & 344.935 & 0.000 & 0.720 \\
Gender & 10.994 & 1 & 10.994 & 1.555 & 0.215 & 0.011 \\
SES & 1.794 & 2 & 0.897 & 0.127 & 0.881 & 0.002 \\
Treatment $*$ Gender & 0.043 & 1 & 0.043 & 0.006 & 0.938 & 0.000 \\
Treatment $*$ SES & 5.809 & 2 & 2.905 & 0.411 & 0.664 & 0.006 \\
Gender $*$ SES & 4.380 & 2 & 2.190 & 0.310 & 0.734 & 0.005 \\
Treatment $*$ Gender $*$ SES & 2.530 & 2 & 1.265 & 0.179 & 0.836 \\
Error & 947.451 & 134 & 7.071 & & & 0.003 \\
Total & 236289.000 & 147 & & & & \\
Corrected total & 4198.653 & 146 & & &
\end{tabular}

Dependent variable: postattitude rating. $\mathrm{R}$ squared $=0.774$ (adjusted $R$ squared $=0.754$ ). Computed using alpha $=0.05$.

TABle 3: Postattitude rating by treatment estimated marginal means.

\begin{tabular}{lcccc}
\hline \multirow{2}{*}{ Interval } & \multicolumn{3}{c}{$95 \%$ confidence } \\
Treatment & Mean & $\begin{array}{c}\text { Std. } \\
\text { Error }\end{array}$ & $\begin{array}{c}\text { Lower } \\
\text { bound }\end{array}$ & $\begin{array}{c}\text { Upper } \\
\text { bound }\end{array}$ \\
\hline Guided discovery (GD) & $45.005^{\mathrm{a}}$ & 0.358 & 44.296 & 45.714 \\
Conventional & $35.840^{\mathrm{a}}$ & 0.307 & 35.232 & 36.447 \\
\hline
\end{tabular}

Covariates appearing in this model were evaluated at these values: pretest $=34.7279$.

hypothesis was not rejected. This implied that the divergence in the postattitude scores of the participants based on their SES was not significant.

$\mathbf{H}_{\mathbf{0 4}}$ : gender and socioeconomic status have no statistically significant main effect on students' retention of Financial Accounting concepts.

Table 5 affirms no significant main effect of gender on students' retention in Financial Accounting concepts $\left.F_{(1,134)}=1.545, p>0.05 ; \eta^{2}=0.011\right)$. Therefore, the null hypothesis was not rejected. This implied that the difference in the retention test scores of the male and female participants was not significant. This result affirmed that the instructional strategies' efficacies were common for both male and female students in financial accounting concepts.

Table 5 also shows that there was no significant main effect of SES on students' retention in Financial Accounting concepts $\left.F_{(2,134)}=0.505, p>0.05 ; \eta^{2}=0.007\right)$. Therefore, the null hypothesis was not rejected. This implied that the diversity in the retention test scores of the students based on their SES was not significant.

Regarding hypothesis five, Table 5 shows that there was no significant two-way interaction effect of treatment and gender on students' retention in Financial Accounting concepts $\left(F_{(1,134)}=2.034, p>0.05 \eta^{2}=0.15\right)$. Hence, the null hypothesis was, therefore, not rejected.

$\mathbf{H}_{\mathbf{0 6}}$ : interaction effect of treatment and socioeconomic status on students' retention of Financial Accounting concepts is not statistically significant.

Table 5 shows that there was no significant two-way interaction effect of treatment and socioeconomic status on students' retention in Financial Accounting concepts $\left(F_{(2,134)}=0.535, p>0.05 \eta^{2}=0.08\right)$. This implied that treatment and socioeconomic status had no significant interaction effect on students' retention in Financial Accounting concepts. Hence, the null hypothesis was, therefore, not rejected.

\section{Discussion}

The effectiveness of guided discovery instructional strategy in advancing students' learning outcomes (attitude and retention) in the concepts selected in Financial Accounting compared to conventional lecture method (Olulowo et al. [57]) was investigated in this study. The first and second hypotheses were on the treatment's effect (instructional strategies) on the learning outcomes (attitude and retention) in participants in Financial Accounting concepts selected from the senior school syllabus. The learning outcomes (attitude and retention) in the participants in Financial Accounting concepts significantly improved consequently on the treatments the experimental group underwent. The learners taught with guided discovery greatly improved on their attitude and retention of Financial Accounting concepts. This result indicated that guided discovery instructional strategy was more productive in improving students' retention and attitude to Financial Accounting concepts.

The efficacy of guided discovery instructional strategy could be credited to the fact that students participate actively at every stage of the instructional model. This strategy, according to Olorode and Jimoh [39], empowers learners to think and discover facts that are necessary to solve Financial Accounting problems independently. Guided discovery has the instructional capacity to enable students to reorganize or revamp existing information to create innovative concepts or principles [40]. In addition, Simamora et al. [21] opined that this instructional model improves learners' propensity in innovation, investigation, problem solving, and autonomous thoughts, formation, and detection through ingenious learning. As regards attitude, this finding conforms with the findings of Ajewole [28] that examined the effects of discovery and expository instructional methods on students' attitude to Biology, which reported that learners exposed to 
TABLE 4: Bonferroni's postattitude rating by treatment.

\begin{tabular}{lcccccc}
\hline & & & & \multicolumn{2}{c}{$95 \%$ confidence interval } \\
(I) Treatment & (J) Treatment & Mean difference (I-J) & Std. Error & Sig. $^{\text {b }}$ & Lower bound & Upper bound \\
\hline Guided discovery & Conventional & $9.165^{\mathrm{a}}$ & 0.493 & 0.000 & 8.189 & 10.141 \\
Conventional & Guided discovery & $-9.165^{\mathrm{a}}$ & 0.493 & $0.000 \mathrm{a}$ & -10.141 & -8.189 \\
\hline
\end{tabular}

Based on estimated marginal means. ${ }^{a}$ Mean difference is significant at 0.05 level. ${ }^{b}$ Multiple comparisons adjustment: Bonferroni.

TABLE 5: Summary of analysis of covariance (ANCOVA) of retention test of students by treatments, gender, and SES.

\begin{tabular}{lcccccc}
\hline Source & Type III sum of squares & Df & Mean square & F & Sig. & Partial eta squared \\
\hline Corrected model & $5038.718^{\mathrm{a}}$ & 12 & 419.893 & 297.045 & 0.000 & 0.964 \\
Intercept & 94.715 & 1 & 94.715 & 67.004 & 0.000 & 0.333 \\
Pretest & 29.057 & 1 & 29.057 & 20.555 & 0.000 & 0.133 \\
Treatment & 544.832 & 1 & 544.832 & 385.431 & 0.000 & 0.742 \\
Gender & 2.185 & 1 & 2.185 & 1.545 & 0.216 & 0.011 \\
SES & 1.428 & 2 & 0.714 & 0.505 & 0.605 & 0.007 \\
Treatment $*$ gender & 2.875 & 1 & 2.875 & 2.034 & 0.156 & 0.015 \\
Treatment $*$ SES & 1.512 & 2 & 0.756 & 0.535 & 0.587 & 0.008 \\
Gender $*$ SES & 5.801 & 2 & 2.901 & 2.052 & 0.132 & 0.030 \\
Treatment $*$ gender $*$ SES & .364 & 2 & 0.182 & 0.129 & 0.879 \\
Error & 189.418 & 134 & 1.414 & & & 0.002 \\
Total & 61496.000 & 147 & & & & \\
Corrected total & 5228.136 & 146 & & &
\end{tabular}

Dependent variable: retention test. $R$ squared $=0.964$ (adjusted $R$ squared $=0.961$ ). Computed using alpha $=0.05$.

TABLE 6: Estimated marginal means for retention test by treatment.

\begin{tabular}{lcccc}
\hline & & & \multicolumn{2}{c}{$95 \%$ confidence interval } \\
Treatment & Mean & Std. Error & Lower bound & Upper bound \\
\hline Guided discovery (GD) & $25.127^{\mathrm{a}}$ & 0.298 & 24.538 & 25.716 \\
Conventional & $15.381^{\mathrm{a}}$ & 0.238 & 14.911 & 15.851 \\
\hline
\end{tabular}

Covariates appearing in this model were evaluated at these values: pretest $=16.4830$.

TABLE 7: Bonferroni's analysis of retention test by treatment.

\begin{tabular}{|c|c|c|c|c|c|c|}
\hline \multirow[b]{2}{*}{ (I) Treatment } & \multirow[b]{2}{*}{ (J) Treatment } & \multirow[b]{2}{*}{ Mean difference $(\mathrm{I}-\mathrm{J})$} & \multirow[b]{2}{*}{ Std. Error } & \multirow[b]{2}{*}{$\operatorname{Sig}^{\mathrm{b}}$} & \multicolumn{2}{|c|}{ 95\% confidence interval } \\
\hline & & & & & Lower bound & Upper bound \\
\hline Guided discovery & Conventional & $9.746^{\mathrm{a}}$ & 0.496 & 0.000 & 8.764 & 10.728 \\
\hline Conventional & Guided discovery & $-9.746^{\mathrm{a}}$ & 0.496 & $0.000^{\mathrm{a}}$ & -10.728 & -8.764 \\
\hline
\end{tabular}

Based on estimated marginal means. ${ }^{a}$ Mean difference is significant at 0.05 level. ${ }^{b}$ Multiple comparisons adjustment: Bonferroni.

guided discovery developed better attitudes to science-related concepts than subjects in the control group. This implies that students taught with guided discovery had better attitudes to Biology than the subjects in the control group. In a similar vein, this finding is in conformity with the findings of Casad and Jawaharlal [41] and Amiyani and Widjajanti [42] who in their separate studies reported the effectiveness of guided discovery instructional strategy in improving students' attitude.

For retention, this finding concurs with the findings of Lasisi et al. [43] that reported a significant difference in the Chemistry attainment of students with guided discovery, problem solving, and conventional lecture method. Lasisi et al. [43] further opined that guided discovery seems the most reliable strategy from the strategies evaluated in their study. In a like manner, Ibe [44] and Akanbi and Kolawole [45], in their separate study, reported significant differences between the retention of students taught Biology with guided discovery and those taught with the conventional method. This implies that guided discovery is better at enhancing students' retention than conventional teaching method. The high retention score of Financial Accounting students in guided discovery group may be attributed to students' encouragement to work together as a team in order to attain group goals, the autonomous discovery of knowledge, and take control of their study with active facilitation of the teacher. Guided discovery strategy is different from conventional teaching method which make students flaccid receivers of knowledge from their teachers.

Regarding the third hypothesis on the significance of gender and socioeconomic status on students' attitude to Financial Accounting, the analysis of data showed that the difference in the attitudinal mean scores of male and female learners in Financial Accounting concepts was not 
significant. This finding does not support the assertion of Imasuen and Omorogbe [29] which established significant differences between the attitude of male and female students in Mathematics. On the other hand, this finding is in conformity with the finding of Sofiani et al. [46] who reported that gender's influence on students' attitude to science was not significant. Also, it could be seen from this finding that socioeconomic status had no significant effect on the participants' attitude. This finding does not support Edosomwan and Edosomwan's [47] finding on the relationship between socioeconomic status and students' attitude to Computer Science.

Furthermore, the effect of gender and socioeconomic status on participants' retention showed that no dissimilarity was evident in the participants' mean retention scores in Financial Accounting concepts. The findings conflict with the outcomes of research conducted by Bosede [48], Lawal [49], and Ugwu [50] that significant differences are featured in male and female students' retention of Science, Chemistry, and Biology concepts. However, this result concurred with Udu's [51], Oludipe's [52], and Iloputaife's [53] findings that reported no gender influence on the academic retention of their participants in Chemistry, Basic Science, and Physics. It was evident from this research that gender was not statistically important for participants' knowledge retention when exposed to student-centered and action-oriented strategies. Also, socioeconomic status had no significant main effect on students' retention which negated the findings of Edinyang et al. [54] that socioeconomic status had a significant main effect on knowledge retention of students in Social Studies.

Moreover, it was evident from the outcome of this study that the interaction effect of treatment and gender on academic retention of students in Financial Accounting concepts was not significant. This means that the guided discovery instructional strategy is not gender-specific as it offers common opportunities to male and female learners. This is in harmony with the findings of Ajai et al. [55], Ogundola [38], and Udu [51], who in their separate studies discovered that treatment would not significantly interact with gender to influence knowledge retention of the student in algebra, Technical Drawing, and Chemistry, respectively. Though, on the other hand, the outcome of the analysis deviates from the inference of Ezeudu [56] on the existence of a significant interaction of treatment and gender on the knowledge and retention of students in Chemistry. The analyses of data gathered for this study on the interaction effect of treatment and gender upheld other studies that discovered that treatment does not rely on the gender of students to be efficient. This implies that the relative efficacy of guided discovery was consistent across gender groups (Olulowo et al.) [57]. Finally, treatment and socioeconomic status did not significantly interact with students' retention in Financial Accounting concepts. This finding confirms the finding of Edinyang et al. [54], who found that there was no significant interaction effect of treatment and socioeconomic status on students' achievement and retention in Social Studies.

\section{Conclusion and Suggestions}

The crucial culmination that can be inferred from this study is that guided discovery proved better in improving learning outcomes (attitude and knowledge retention) in students in Financial Accounting concepts. Also, guided discovery is not gender inclined and its effectiveness is not based on students' socioeconomic status. Consequent to the outcomes of this study and prior research on improvement of students' learning outcomes (attitude and knowledge retention), guided discovery is vastly suggested for curriculum implementers (teachers), administrator, and curriculum developers whose utmost priority is to improve students' attitude, knowledge, and retention in Financial Accounting as it props up and eggs on social interaction, energetic learning that enhances attitude and knowledge retention. On the other hand, this study only considered senior secondary school two students who were offering Financial Accounting. In this wise, the findings of this study cannot be generalized to other levels of students offering Financial Accounting in senior secondary schools. The researchers, therefore, recommended that further studies should be experimented on students offering Financial Accounting in senior secondary schools and tertiary institutions. Also, future research could explore improvements in other academic and psychological variables, such as self-efficacy and critical thinking in Financial Accounting using guided discovery instructional strategy.

\section{Data Availability}

The data used to support the findings of this study are included within the article.

\section{Conflicts of Interest}

The authors declare no conflicts of interest.

\section{References}

[1] Federal Republic of Nigeria, National Policy on Education, Lagos: Nigerian Educational Research and Development Council (NERDC) Press, Ikega, Nigeria, 4 edition, 2004.

[2] O. S. Obianuju, E. O. Akuezuilo, and J. N. Okoli, "Effect of multiple intelligence-based instructional technique (MIBIT) on students' interest in the learning of difficult Biology concepts," IOSR Journal of Research \& Method in Education (IOSR-JRME), vol. 5, no. 3, pp. 1-9, 2015.

[3] J. O. Ezeugwu, G. C. Nji, N. J. Anyaegbunam, C. Enyi, and R. U. Eneja, "Influence of cognitive ability, gender and school location on students' achievement in senior secondary school financial accounting," European Journal of Economics, Finance and Administrative Sciences, vol. 89, pp. 97-117, 2016.

[4] R. O. Toluwalope, Importance and Function of Accounting, http://www.gemanalyst.com/importance-and-function-ofaccounting/, 2016.

[5] B. G. Omoni, O. A. Omonze, and F. C. Nwosu, "Students' performance in financial accounting: implications for business organizations in the Niger delta," International Journal of Business \& Law Research, vol. 6, no. 4, pp. 56-62, 2018. 
[6] A. A. Udoh, "Business education teachers' perceptive assessment of secondary school students' academic performance in financial accounting," Nigerian Association of Business Educators, vol. 3, no. 1, pp. 45-51, 2003.

[7] National Examination Council, Regulations and Syllabus for Senior Secondary School Certificate Examination, NECO, Minna, Nigeria, 2004.

[8] F. C. Nwaukwa and C. C. Okolocha, "Effect of think-pairshare instructional strategy on students' academic achievement and self-efficacy in financial accounting in Abia state," International Journal of Recent Innovations in Academic Research, vol. 4, no. 1, pp. 37-48, 2020.

[9] I. Umar and U. B. Abdulmutallib, "Effects of cooperative and guided discovery approach on financial accounting achievement among secondary school students," ATBU, Journal of Science, Technology \& Education, vol. 5, no. 2, pp. 61-70, 2017.

[10] V.S. Andrini, "The effectiveness of inquiry learning method to enhance students' learning outcome: a theoretical and empirical review," Journal of Education and Practice, vol. 7, no. 3, pp. 38-42, 2016.

[11] M. Phillips, A Place for Learning: The Physical Environmentof-Classrooms, http://ww.edutopia.org/blog/the-physicalenvironment-of-classrooms-mark-phillips, 2016.

[12] R. W. Bybee, "Scientific and engineering practices in K-12 classrooms: "understanding a framework for K-12 science education,” Science Scope, vol. 35, no. 4, pp. 6-11, 2011.

[13] C. Jordan, "Beginning teacher knowledge: results from a selfassessed TPACK survey," Australian Educational Computing, vol. 26, no. 1, pp. 16-26, 2011.

[14] T. J. Wu and Y. N. Tai, "“"Effects of multimedia information technology integrated multi-sensory instruction on students' learning motivation and outcome," Eurasia Journal of Mathematics, Science \& Technology Education, vol. 12, no. 4, pp. 1065-1074, 2016.

[15] E. M. Nilssom and A. Jakobsson, "Simulated sustainable societies: students' reflections on creating future cities in computer games'," Journal of Science Education and Technology, vol. 20, no. 1, pp. 33-50, 2011.

[16] C. Nwagbo, "Effects of two teaching methods on the achievement in and attitude to biology of students of different levels of scientific literacy," International Journal of Educational Research, vol. 45, no. 3, pp. 216-229, 2006.

[17] A. Nasreen and A. Naz, "A study of factors effecting academic achievement of prospective teachers," Journal of Social Science for Policy Implications, vol. 1, no. 1, pp. 23-31, 2013.

[18] A. C. Okoye, "Effect of audio taped instructions supported with pictures on students' achievement and retention in selected biology contents," Unpublished M.Ed. Thesis, Nsukka Library, University of Nigeria, Nsukka, 2003.

[19] A. A. P. Yerizon and M. Subhan, "Mathematics learning instructional development based on discovery learning for students with intrapersonal and interpersonal intelligence (preliminary research stage)," International Electronic Journal of Mathematics Education, vol. 13, no. 3, pp. 97-101, 2018.

[20] A. G. Balım, "The effect of discovery learning on students' success and inquiry learning skills," Egitim ArastirmalariEurasian Journal of Educational Research, vol. 35, no. 2, pp. 1-20, 2009.

[21] R. E. Simamora, S. Saragih, and A. Hasratuddin, "Improving students' mathematical problem solving ability and self-efficacy through guided discovery learning in local culture," International Electronic Journal of Mathematics Education, vol. 14, no. 1, pp. 61-72, 2019.
[22] V. N. Khasanah, B. Usodo, and S. Subanti, "Discovery learning with scientific approach on (ICMScE)," IOP Publishing IOP Conference Series: Journal of Physics: Conference Series, vol. 895, Article ID 012033, 2017.

[23] C. Nwagbo, "Effects of guided-discovery and expository teaching methods on the attitudes towards biology of students of with different levels of scientific literacy," Journal of the Science Teachers Association of Nigeria, vol. 36, no. 1\&2, pp. 43-51, 1999.

[24] F. Afolabi and A. O. Akinbobola, "Constructivist problem based learning technique and the academic achievement of physics students with low ability level in Nigerian secondary schools," Eurasian Journal of Physics and Chemistry Education, vol. 1, no. 1, pp. 45-51, 2009.

[25] C. J. Shieh and L. A. Yu, "Study on information technology integrated guided discovery instruction towards students' learning achievement and learning retention," Eurasia Journal of Mathematics, Science \& Technology Education, vol. 12, no. 4, pp. 833-842, 2016.

[26] A. O. Bamiro, "Effects of guided discovery and think-pairshare strategies on secondary school students' achievement in chemistry," The International Journal of Technologies in Learning, vol. 21, no. 1, pp. 1-7, 2015.

[27] R. Hake, "Lessons from the physics education ecology," Conservation Ecology, vol. 5, no. 2, 2002.

[28] G. A. Ajewole, "Effect of discovery and expository instructional methods on the attitude of students to biology," $A$ Journal of Research in Science Teaching, vol. 28, no. 18, pp. 401-409, 2008.

[29] K. Imasuen and D. E. A. Omorogbe, "The influence of gender on junior secondary school students attitude towards Mathematics in Ovia north east local government area of Edo state," African Research Review, vol. 10, no. 4, pp. 115-126, 2016.

[30] F. C. Anyanwu and O. N. H. Oyenuga, "The impact of sex education intervention on knowledge of male undergraduates towards the use of family planning methods in Ogun state, Nigeria," in Proceedings of the 53rd ICHPER-SD Anniversary World Congress Sponsored by the Sport Science Association (SSA) of Egypt, E. Torabi, Ed., pp. 222-227, Cario, Egypt, December 2011.

[31] O. A. Ige, "Impact of an action cyber crime prevention programme on secondary school students' learning outcomes in civic education and social studies concepts," Unpublished Ph.D. thesis, University of Ibadan, Nigeria, 2013.

[32] P. A. Amosun, O. A. Ige, and K.-K. R. Choo, "Impact of a participatory cyber crime prevention programme on secondary school students' attainment in crime prevention concepts in civic education and social studies," Education and Information Technologies, vol. 20, no. 3, pp. 505-518, 2015.

[33] O. A. Ige, "Effects of gender and technological fluency on learners' attitude to cybercrime prevention in urban learning ecologies: "lessons for Swedish gymnasiums"” International Journal of Cyber Criminology, vol. 12, no. 1, pp. 151-170, 2018.

[34] O. A. Ige, "Effects of value clarification and action learning instructional strategies on school-age children's attitude to civic education concepts: "The mountain learning ecologies experience," Pedagogika, vol. 131, no. 3, pp. 83-98, 2018.

[35] O. A. Ige, "Using action learning, concept-mapping, and value clarification to improve students' attainment in ICT concepts in social studies: the case of rural learning ecologies," Journal of Social Studies Education Research, vol. 10, no. 1, pp. 301322, 2019. 
[36] F. Adesoji and I. Ibraheem, "Effects of student teamsachievement divisions strategy and mathematics knowledge on learning outcomes in chemical kinetics," Journal of International Social Research, vol. 2/6, 2009.

[37] A. Ali, Introduction to Research Methodology in Education, Fulladu Publishers, Obosi, 1996.

[38] P. Ogundola, "Effects of peer tutoring strategy on academic achievement of senior secondary school students in technical drawing in Nigeria," British Journal of Education, Society \& Behavioural Science, vol. 19, no. 1, pp. 1-10, 2017.

[39] J. J. Olorode and A. G. Jimoh, "Effectiveness of guided discovery learning strategy and gender sensitivity on students' academic achievement in financial accounting in colleges of education," International Journal of Academic Research in Education and Review, vol. 4, no. 6, pp. 182-189, 2016.

[40] C. De Smet, J. Bourgonjon, B. De Wever, T. Schellens, and M. Valcke, "Researching instructional use and the technology acceptation of learning management systems by secondary school teachers," Computers \& Education, vol. 58, no. 2, pp. 688-696, 2012.

[41] B. J. Casad and M. Jawaharlal, "Learning through guided discovery: an engaging approach to K-12 STEM education," in Paper Presented at 2012 ASEE Annual Conference \& Exposition, San Antonio, Texas, June 2012.

[42] R. Amiyani and J. B. Widjajanti, "The excellence of guided discovery learning on mathematical knowledge-based, skillbased, and attitude," Journal of Physics: Conference Series, vol. 1097, pp. 1-7, 2018.

[43] N. Lasisi, T. O. Alabi, and M. B. Salaudeen, "Comparison of the effects of guided discovery, problem solving and conventional teaching methods on retention of secondary school Chemistry students in Minna Metropolis, Niger State," American Journal of Innovative Research and Applied Sciences, vol. 2, no. 3, pp. 98-104, 2016.

[44] H. N. N. Ibe, "Effects of guided discovery-inquiry and expository teaching methods on senior secondary school students' performances in Biology in Imo State," Journal of Education Research and Behavioral Sciences, vol. 2, no. 4, pp. 51-57, 2013.

[45] A. A. Akanbi and C. B. Kolawole, "Effects of guided discovery and self-learning strategies on senior secondary school students' achievement in Biology," Journal of Educational and Leadership Development, vol. 6, no. 1, pp. 19-42, 2014.

[46] D. Sofiani, A. S. Maulida, N. Fadhillah, and D. Y. Sihite, "Gender differences in students' attitude towards science," Journal of Physics, Conference Series, vol. 895, pp. 1-7, 2017.

[47] J. H. Edosomwan and T. O. Edosomwan, "Correlation between attitude and socioeconomic status of students' performance in computer science," Science Journal of Education, vol. 3, no. 4, pp. 75-77, 2015.

[48] A. F. Bosede, "Influence of sex and location on relationship between student problems and academic performance," The Social Sciences, vol. 5, no. 4, pp. 340-345, 2010.

[49] F. K. Lawal, "Effectiveness of conceptual change instructional strategy in remediating misconceptions in genetics concepts among senior secondary school students in Kano State," Unpublished Ph.D. Thesis, Ahmadu Bello University, Zaria, Nigeria, 2009.

[50] A. U. Ugwu, "Effect of analogy model of instruction on students' achievement and retention in biology in secondary schools in Enugu," Unpublished M.Sc. Thesis, Enugu State University of Science and Technology, Enugu, Nigeria, 2007.

[51] D. A. Udu, "Efficacies of cooperative learning instructional approach, learning activity package, and lecture method in enhancing students' academic retention in chemistry," Science Education International, vol. 29, no. 4, pp. 220-227, 2019.

[52] D. Oludipe, "Gender difference in Nigerian junior secondary students' academic achievement in basic science," Journal of Educational and Social Research, vol. 2, no. 1, pp. 76-81, 2012.

[53] E. C. Iloputaife, "Effect of analogy and conceptual change instructional model on physics achievement of secondary school students," Unpublished PH.D. Thesis, University of Nigeria, Nsukka, 2001.

[54] S. D. Edinyang, I. E. Ubi, E. E. Usang, and R. A. Adalikwu, "Effects of gender, socioeconomic status, teacher qualification and their interaction on students' retention ability in social studies in Akwa Ibom State, Nigeria," Journal of Culture, Society and Development, vol. 2, pp. 35-40, 2013.

[55] J. T. Ajai, B. I. Imoko, and E. I. Okwu, "Comparison of the learning effectiveness of problem-based learning (PBL) and conventional method of teaching algebra," Journal of Education and Practice, vol. 4, no. 1, pp. 132-138, 2013.

[56] F. O. Ezeudu, "Influence of concept maps on achievement retention of senior secondary school students in organic chemistry," Journal of Education and Practice, vol. 4, no. 19, pp. 35-43, 2013.

[57] T. G. Olulowo, O. A. Ige, and E. O. Ugwoke, "Using peer tutoring to improve students' academic achievement in financial accounting concepts," Education Research International, vol. 2020, Article ID 8871235, 10 pages, 2020. 